\title{
Bottlenose dolphin ecotypes of the western South Atlantic: the puzzle of habitats, coloration patterns and dorsal fin shapes
}

\author{
Paulo C. Simões-Lopes ${ }^{1, *}$, Fábio G. Daura-Jorge ${ }^{1}$, Liliane Lodi ${ }^{2}$ Carolina Bezamat $^{1}$, \\ Ana P. B. Costa ${ }^{3,4}$, Leonardo L. Wedekin ${ }^{1,5}$ \\ ${ }^{1}$ Laboratório de Mamíferos Aquáticos, Departamento de Ecologia e Zoologia, Universidade Federal de Santa Catarina, \\ Florianópolis, SC 88040-970, Brazil \\ ${ }^{2}$ Projeto Ilhas do Rio and Projeto Baleias \& Golfinhos do Rio de Janeiro, Instituto Mar Adentro, Rio de Janeiro 22032-071, Brazil \\ ${ }^{3}$ Department of Biology, University of Louisiana at Lafayette, Lafayette, Louisiana 71503, USA \\ ${ }^{4}$ Institute of Biodiversity, Animal Health, and Comparative Medicine, University of Glasgow, Glasgow G12 8QQ, UK \\ ${ }^{5}$ Socioambiental Consultores Associados, Florianópolis 88015-200, Brazil
}

\begin{abstract}
Phenotypic variations occur in several cetacean species, including common bottlenose dolphins Tursiops truncatus, which can also be distinguished as coastal and offshore ecotypes. In the western South Atlantic, these ecotypes have been described based on skeletal morphology and genetics. However, there is still no clear description to recognize them in the field. Here we searched for external diagnostic patterns that may facilitate their visual distinction and investigated their habitat use. We examined dorsal fin shapes and coloration of photo-identified dolphins distributed in a wide geographic range off the coast of southern and southeastern Brazil. A strong differentiation in the dorsal fin shape was observed, with a more falcate shape for offshore dolphins. We also found that offshore individuals have a darker color pattern, while coastal dolphins show 2 wider striped bands at the throat region and a longer rostrum, revealing that the ecotypes can be well distinguished in the field. We also detected differential habitat use. The coastal ecotype inhabits shallow waters (up to $18 \mathrm{~m}$ deep) close to the shore (up to $3 \mathrm{~km}$ ). The offshore ecotype has a wider distribution and more flexible habitat use. It was usually found in coastal and deeper waters (maximum depth of $758 \mathrm{~m}$ and $>200 \mathrm{~km}$ from the coast). Although we observed a small area of overlap in the distribution of the 2 ecotypes, both forms were not seen together. Therefore, our results reinforce the presence of a parapatric distribution and distinct morphology between the ecotypes, supporting their prior description as different subspecies.
\end{abstract}

KEY WORDS: Tursiops truncatus - Coastal/offshore - Distribution - Habitat - Group size · Subspecies $\cdot$ Brazil

\section{INTRODUCTION}

Variability is fundamental for the evolution of organisms. In addition to allelic variability, there is also phenotypic plasticity (West-Eberhard 2003), which allows for the concept of morphological spaces (morphospaces) that describe and relate organismal phenotypes (Eble 2000). This variability needs to be considered when identifying populations, ecotypes, and

\footnotetext{
${ }^{*}$ Corresponding author: simoes_lopes@hotmail.com
}

species. Some genera and species have significant morphospace variation, while others have practically none. The African cheetah Acinonyx jubatus, with a population estimated at $\sim 20000$ individuals in subSaharan Africa (Menotti-Raymond \& O'Brien 1993), and the highly mobile wandering albatross Diomedea exulans and Amsterdam albatross D. amsterdamensis (Milot et al. 2007) are typical examples of species with low variability at the genetic level

() The authors 2019. Open Access under Creative Commons by Attribution Licence. Use, distribution and reproduction are unrestricted. Authors and original publication must be credited. Publisher: Inter-Research · www.int-res.com 
(mtDNA and nuclear DNA). In contrast, geographical variation in morphology and coloration is common in several cetacean species (Perrin 2009). Dolphins of the genus Tursiops Gervais, 1855, for instance, have a recognized morphospace variation, with at least 20 nominal forms that are now largely synonymized (Hershkovitz 1966).

The widely distributed common bottlenose dolphin T. truncatus (Montagu, 1821) is the focus of an intense taxonomic debate. Ecotypes or morphotypes, both coastal and offshore, have been recognized for this species in several parts of the world (e.g. Hersh \& Duffield 1990, Rosel et al. 2009, Tezanos-Pinto et al. 2009, Perrin et al. 2011), including the western South Atlantic Ocean (wSAO) (Costa et al. 2016). Darker skin coloration and a falcate dorsal fin are typically described as being characteristics of the offshore common bottlenose dolphin ecotype, whereas coastal dolphins appear to have lighter coloration and a less falcate dorsal fin shape (Van Waerebeek et al. 1990, Sanino \& Yáñez 2001, Félix et al. 2018).

The proposed existence of coastal and offshore ecotypes in the wSAO was initially based on different color patterns and dorsal fin shapes that resembled the patterns observed worldwide (Simões-Lopes 1996, Cremer et al. 2009, Lodi 2009). However, these observations of external morphological patterns were limited to non-systematic and opportunistic surveys that lacked quantitative data for hypothesis testing. Later, this ecotype hypothesis was tested and described according to skeletal morphology (Toledo 2013, Costa et al. 2016). In fact, the great morphological differentiation observed between these ecotypes led to their description as different subspecies (coastal ecotype: T. truncatus gephyreus; offshore ecotype: T. truncatus truncatus), with an apparently parapatric distribution (Costa et al. 2016). Wickert et al. (2016) argued that these different ecotypes represented different species (T. gephyreus and T. truncatus) living in sympatry along the southern Brazilian coast, the caveat being that distinguishing between those taxa was based on characters that are not consistently present in all the skulls.

More recently, Fruet et al. (2017) biopsied common bottlenose dolphins in coastal and offshore waters of the wSAO, including coastal dolphins off the northern coast of Argentina. Genetic analyses using the mtDNA control region and 11 microsatellite loci demonstrated that all the dolphins biopsied in offshore waters clustered separately from those biopsied in coastal waters. During sampling, those authors observed differences in the external morphology of dolphins from different habitats, which was in congru- ence with that suggested in the literature regarding color-pattern differences between the common bottlenose dolphin ecotypes in the wSAO (e.g. SimõesLopes 1996). Nevertheless, distinguishing between these ecotypes in the field is still not straightforward; this leads to an information gap in ecological issues such as the distribution and habitat use of these 2 forms, factors that are crucial for the application of management or conservation strategies. Moreover, the long-term interaction of these dolphins with their habitats are important drivers of evolutionary change (Acevedo-Gutiérrez 2009), and understanding this relationship may help define ecotypes, as well as infraspecific taxa such as subspecies.

In this article, we compared dorsal fin shapes and coloration of photo-identified common bottlenose dolphins off the coast of southern and southeastern Brazil. We looked for patterns that could distinguish the 2 ecotypes in the field, and evaluated if differences between wSAO ecotypes were potentially similar to those described in the literature for bottlenose dolphin ecotypes in other oceanic regions. First, we investigated whether distinct clusters existed based on differences in quantitative indices used to characterize dorsal fin shapes. Second, we classified the clusters as coastal or offshore ecotypes and examined differences in external morphology (i.e. color pattern and dorsal fin shape) between clusters that could be used in field recognition. Finally, based on our findings, we discussed habitat usage by the 2 ecotypes, describing their distribution and group sizes. In brief, we expect that the ability to distinguish external morphological characters between ecotypes in the field will help to shed light on ecological issues that are essential for the ongoing taxonomic debate, as well as aid in the design and implementation of subspecies-specific management and conservation strategies.

\section{MATERIALS AND METHODS}

\subsection{Dataset}

Digital images of dorsal fins from 43 different groups of dolphins were available for analysis. The images came from long-term photo-identification studies (opportunistic and systematic efforts) and were chosen to maximize the coverage of a latitudinal gradient and the range of marine habitats where the species is known to occur (coastal to offshore and oceanic waters). The following criteria were used to select images from the wSAO (modified from Morteo 
et al. 2017): (1) images of adults only; (2) dorsal fin completely visible; and (3) when possible, images of individuals sighted in different groups. The photographic database $(n=80)$ was prepared by selecting only the images with the highest quality (the best image of each individual; all with high resolution and adequate angle and focus) of a maximum of 5 (when available) dolphins (identified by photo-identification protocols) from each encounter. Opportunistic images obtained from coastal and offshore records were also used to investigate, and then describe, additional phenotypic variations.

The total sample size consisted of 80 individuals with their respective dorsal fin images, 25 of which were obtained from 9 different coastal sites from Itajaí ( $\left.26^{\circ} 54^{\prime} 44^{\prime \prime} \mathrm{S}\right)$ to Rio Grande ( $\left.32^{\circ} 08^{\prime} 32^{\prime \prime} \mathrm{S}\right)$, and 17 obtained from the Abrolhos Bank (19 $\left.30^{\circ} 27^{\prime \prime} \mathrm{S}\right)$, Trindade Island $\left(20^{\circ} 29^{\prime} 33^{\prime \prime} \mathrm{S}, 29^{\circ} 19^{\prime} 15^{\prime \prime} \mathrm{W}\right)$, Grande Island $\left(23^{\circ} 13^{\prime} 12^{\prime \prime} \mathrm{S}\right)$, and Cagarras Archipelago $\left(23^{\circ} 04^{\prime} 14^{\prime \prime} \mathrm{S}\right)$. The other 38 images were obtained during systematic ship-based surveys (Cetacean Monitoring Project in Santos Basin [PMC-BS]) carried out in the Southern Brazilian Bight and in waters off the south and southeast of Brazil, and included groups sighted in coastal, shelf, slope, and oceanic waters.

Considering the evidences of genetic connectivity between offshore dolphins of the western North Atlantic and common bottlenose dolphins elsewhere (e.g. Tezanos-Pinto et al. 2009, Louis et al. 2014), including the offshore dolphins of wSAO (A. P. B. Costa unpubl. data), as well as previous findings of similarities in external morphology (i.e. dorsal fin falcateness) between dolphins inhabiting deeper waters in the eastern Pacific (Morteo et al. 2017, Félix et al. 2018), we aimed to investigate the potential phenotypic similarity in the dorsal fin shape between offshore dolphins of other oceanographic regions with the ecotypes of the wSAO. Therefore, we used 1 dorsal fin image obtained from the offshore waters of the Galapagos Islands (and included in the ordination procedure-see Sections 2.2 and 2.3) and another from the western North Atlantic (recognized as an offshore ecotype by morphological and genetic analyses, W. McFee \& P. E. Rosel pers. comm.).

\subsection{Digital measurements of dorsal fin shape}

Image J software (Schneider et al. 2012) was used to define 6 landmarks on the dorsal fins, modified from Morteo et al. (2017), and to measure the distance between them (Fig. 1). Each landmark was established based on angles that depicted the shape of the dorsal fin. Distances between landmarks were used to define 4 indices for each image through the following standardized ratios (see Weller 1998, Morteo et al. 2017): $\mathrm{C} 30 \mathrm{~B} / \mathrm{AB}, \mathrm{C} 20 \mathrm{~B} / \mathrm{AB}, \mathrm{C} 10 \mathrm{~B} / \mathrm{AB}$, and $\mathrm{C} 5 \mathrm{~B} / \mathrm{AB}$ (Fig. 1). These landmarks and indices were chosen according to the ease of detection of differences in the falcate and triangular fin shape previously proposed for the offshore and coastal ecotypes of the wSAO, respectively (following descriptions in Simões-Lopes 1996). The landmark measurements were kept as simple as possible to facilitate replication in future studies that need to identify ecotypes through photo-identification records. We used the mean of 3 replicates of all the dorsal fin measurements, performed by a single trained operator (F. G. Daura-
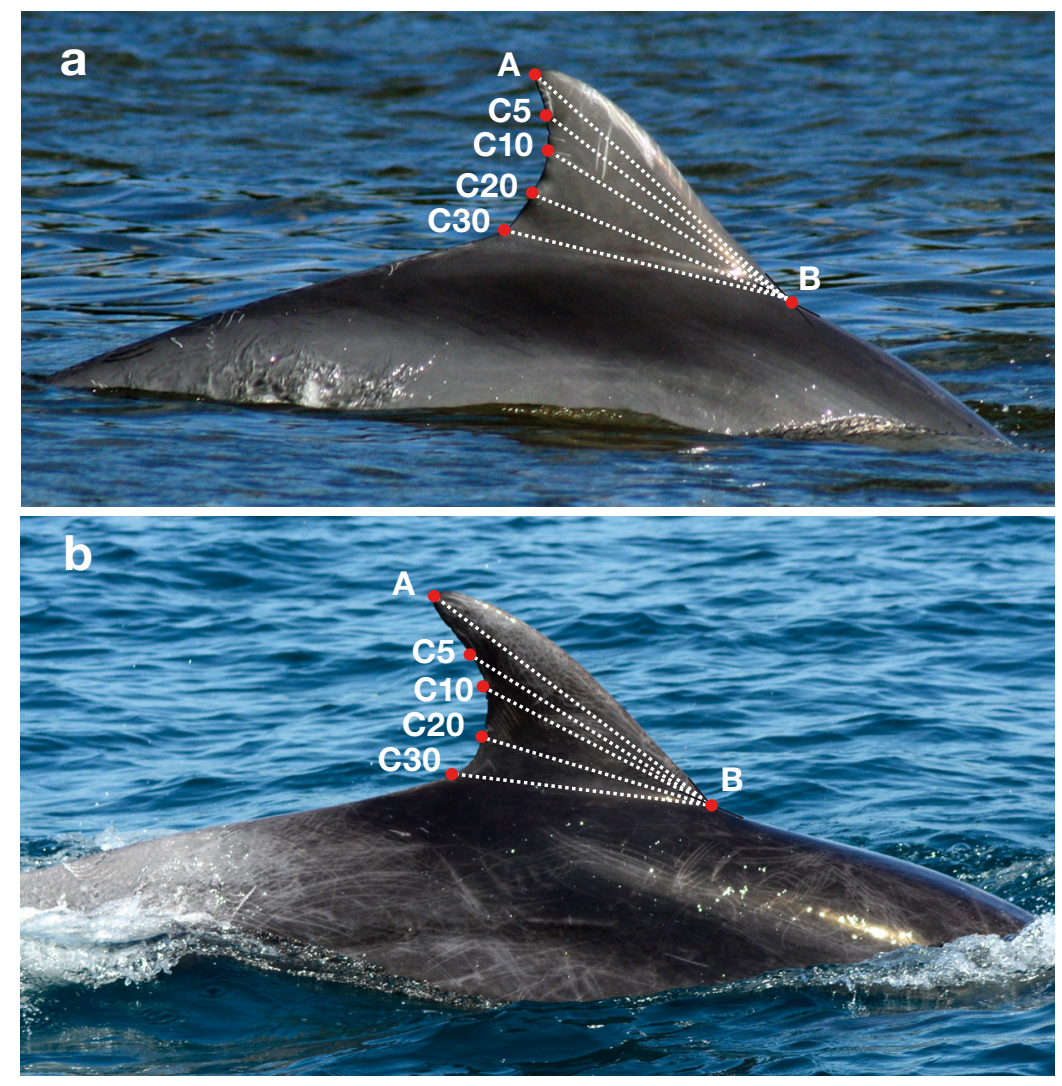

Fig. 1. Landmarks, measurements, and indices obtained from images of (a) coastal and (b) offshore dolphins using ImageJ. A: apex of the dorsal fin; B: intersection between the 2 lines parallel to the frontal base; $\mathrm{C} 5$ : defined by the $5^{\circ}$ angle to line $A B ; C 10$ : defined by the $10^{\circ}$ angle to line $A B ; C 20$ : defined by the $20^{\circ}$ angle to line $A B_{;} \mathrm{C} 30$ : defined by $30^{\circ}$ angle to line $\mathrm{AB}$ 
Jorge). Measurement variance was minimal and negligible and did not affect the analysis.

\subsection{Statistical analysis of dorsal fin classification}

A principal component analysis (PCA) was conducted to evaluate if the quantitative indices of the dorsal fin supported the presence of different clusters. A $K$-means algorithm was applied to the principal components to verify the PCA results and cluster the dorsal fins into 2 groups. Discriminant function analysis (DFA) was then used on 14 samples of known provenance $(7$ from coastal individuals from a resident population in Laguna, southern Brazil, and 7 from offshore individuals from Abrolhos Bank and Trindade Island) to create a classifier using the quantitative indices. DFA models can identify a linear combination of quantitative predictor variables that best characterize the separation between groups. Variables are combined into 1 or more discriminant functions that assign each one to its appropriate group (correct assignment), or a different group (incorrect assignment). The larger the standardized coefficients for each variable in each discriminant function, the greater the contribution of the respective variable to the discrimination between groups. Instead of the full DFA model, backward stepwise leave-one-out cross-validation was used for all quantitative indices to identify a reduced model that identifies the best predictor variables. The best model was used as a classifier in a second round of DFA applied to samples of unknown origin. Finally, the concordance between the unsupervised cluster assignment was compared by $K$-means algorithm, and the classifications by DFA, to verify if the PCA distribution corresponded to the different ecotypes. In addition, a multivariate analysis of variance (MANOVA) and Hotelling $T^{2}$ test were used to examine partitioning of multivariate variance. The data used for the quantitative indices were tested for normality (Shapiro-Wilk test) and log-transformed when necessary. All statistical analyses were performed in $\mathrm{R}$ version 3.1.1 (R Core Team 2014), using the 'MASS' (Venables \& Ripley 2002) and 'vegan' (Oksanen et al. 2018) packages.

\subsection{Additional phenotypic variations}

After the samples were classified by $K$-means clustering, additional phenotypic differences observed in other images from the groups where the clustered samples originated were investigated and described opportunistically. The following characteristics were qualitatively compared in the images: the dorsal cape, the spinal blaze, the presence and pattern of teeth marks (in the tip and posterior edge of the dorsal fin, dorsal ridge, and tailstock), the color pattern on the throat region, the presence of spots on the belly, and the pattern of stripes on the melon region and close to the eye. Differences in rostrum size (see Fig. S1 and 'Rostrum size preliminary analysis' and Fig. S2 in Supplement 1 at www.int-res.com/articles/ suppl/b028p101_supp.pdf) were also preliminarily investigated in 20 images of the head of 10 individuals of each ecotype.

\subsection{Habitat use and group size}

Samples from the coastal and offshore $K$-meansgenerated clusters (see Section 3.1) were used to investigate differences in ecological parameters between ecotypes. One sample was excluded from the analysis due to mismatch between the classification of $K$-means clusters and DFA. For each group of common bottlenose dolphins, the group size, geographical position, distance from shore, and depth were recorded based on the ETOPO1 bathymetric model of the study area, with $1^{\circ}$ of resolution, using the $\mathrm{R}$ package 'marmap' (Pante \& Simon-Bouhet 2013). By considering only group records, pseudoreplication was avoided and independence was assured among observations. To test differences in habitat use between ecotypes, $t$-tests were performed for data on log-transformed distance from shore and log-transformed depth. Data transformation was necessary to ensure homoscedasticity.

Additionally, a generalized linear model (GLM) with zero-truncated negative binomial distribution of errors, group size as the response variable, and ecotype as a dummy variable, were used to test whether differences in group sizes between ecotypes were statistically significant. The model was fit to the data using the package 'VGAM' (Yee et al. 2015).

\section{RESULTS}

\subsection{Dorsal fin variation}

The first 2 components of the PCA accounted for $97.1 \%$ of the data variance, suggesting the complexity of the dataset can be reduced to 2 components with only $2.9 \%$ loss of information (Fig. 2). The most 


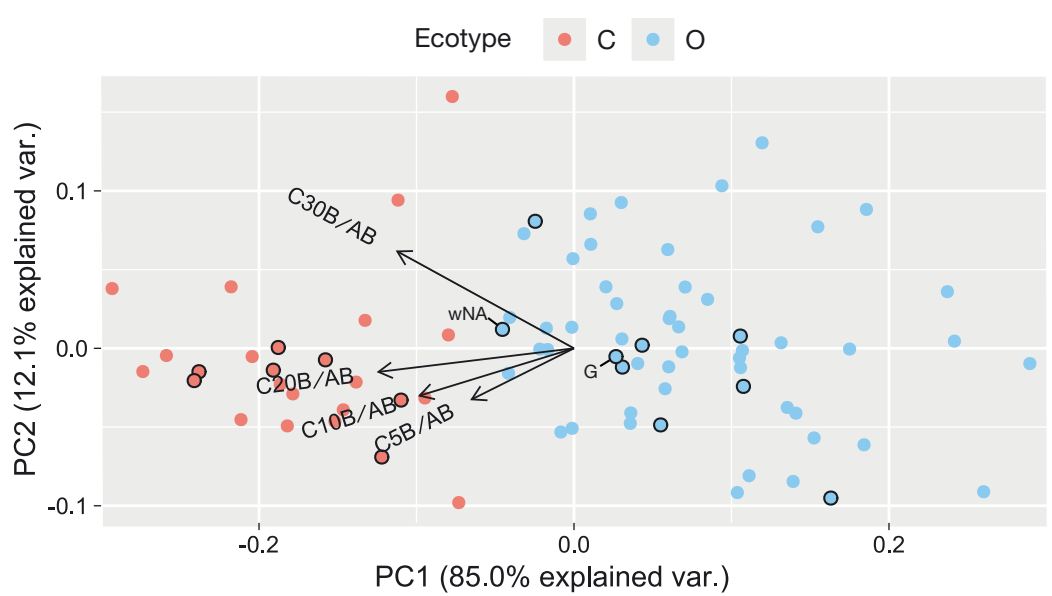

Fig. 2. Biplot of the PCA of 4 dorsal fin indices obtained from 82 images of dorsal fins of common bottlenose dolphins of southern and southeastern Brazil. Two clusters were separated (see Section 3.1) by a $K$-means algorithm applied to PCA loadings. Red: coastal cluster $(\mathrm{C})$; blue: offshore cluster $(\mathrm{O})$; colored circles with black outline: samples of known origin. Offshore samples from the western North Atlantic (wNA) and Galapagos Islands (G) plotted within the offshore cluster. $\mathrm{C} 5 \mathrm{~B} / \mathrm{AB}$ : ratio between the distances $\mathrm{C} 5 \mathrm{~B}$ and $\mathrm{AB} ; \mathrm{C} 10 \mathrm{~B} / \mathrm{AB}$ : ratio between the distances $\mathrm{C} 10 \mathrm{~B}$ and $\mathrm{AB} ; \mathrm{C} 20 \mathrm{~B} / \mathrm{AB}$ : ratio between the distances $\mathrm{C} 20 \mathrm{~B}$ and $A B ; C 30 B / A B$ : ratio between the distances $C 30 B$ and $A B$ (see also Fig. 1)
Indeed, the best explanatory DFA model applied to samples of known origin included the 4 indices (Ecotype $23.69 \cdot \mathrm{C} 30 \mathrm{~B} / \mathrm{AB}-160.61$. $\mathrm{C} 20 \mathrm{~B} / \mathrm{AB}+151.44 \cdot \mathrm{C} 10 \mathrm{~B} / \mathrm{AB}-106.97$. C5B/AB). This full model had a $100 \%$ ability to separate samples, concurring with our previous classification based on knowledge of sample provenance. By using this full model as a classifier, the DFA applied to the samples of unknown provenance validated the 2 clusters (hereinafter termed as coastal and offshore ecotypes) defined by the $K$-means algorithm with $98 \%$ concordance (see Fig. S3 in Supplement 2). Measurements from offshore common bottlenose dolphins from the Galapagos Islands and western North Atlantic also clustered as offshore by the $K$ means algorithm, being consistent with the findings from the classifica- informative variables for PC1 were C30B/AB (loading > 0.5) and C20B/AB (loading > 0.6). However, all 4 dorsal indices were smaller for the offshore cluster (C30B/AB, mean: 0.79, range: 0.66-0.90; C20B/AB, mean: 0.70 , range: $0.63-0.75 ; \mathrm{C} 10 \mathrm{~B} / \mathrm{AB}$, mean: 0.74 , range: $0.68-0.79$; $\mathrm{C} 5 \mathrm{~B} / \mathrm{AB}$, mean: 0.83, range: 0.75$0.90)$ than for the coastal cluster $(C 30 B / A B$, mean: 0.90, range: $0.80-1.01$; $\mathrm{C} 20 \mathrm{~B} / \mathrm{AB}$, mean: 0.82, range: $0.74-0.90 ; \mathrm{C} 10 \mathrm{~B} / \mathrm{AB}$, mean: 0.84, range: 0.75-0.89; C5B/AB, mean: 0.90, range: 0.83-0.93; Fig. 3), consistent with a more falcate dorsal fin shape for the offshore ecotype.
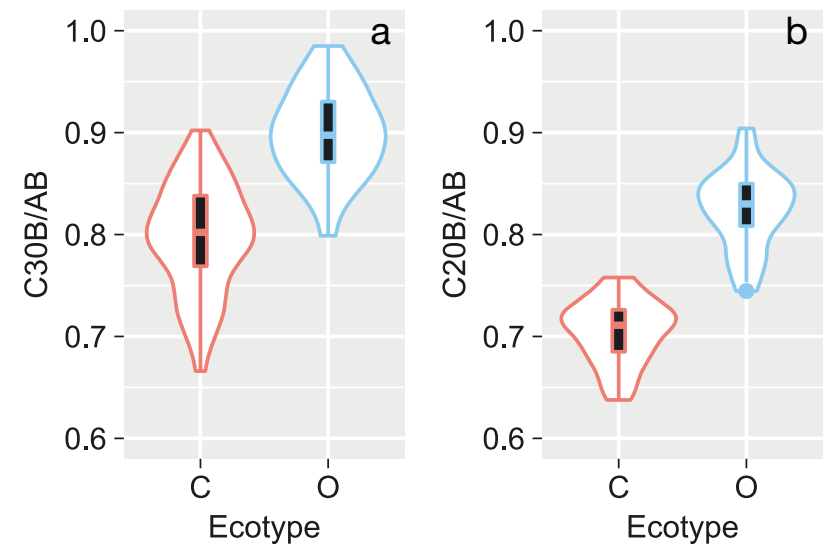

tion. Finally, the resulting separation was significant (MANOVA, Hotelling $T^{2}=6.15$; df $=2$; $F=$ 169.31; $\mathrm{p}<0.001)$.

\subsection{Additional phenotypic variations}

In the images from groups with clustered samples, we observed that the distinct external morphological features that we examined, summarized in Table 1, had potential for use in ecotype identification (Fig. 4). Compared to coastal individuals
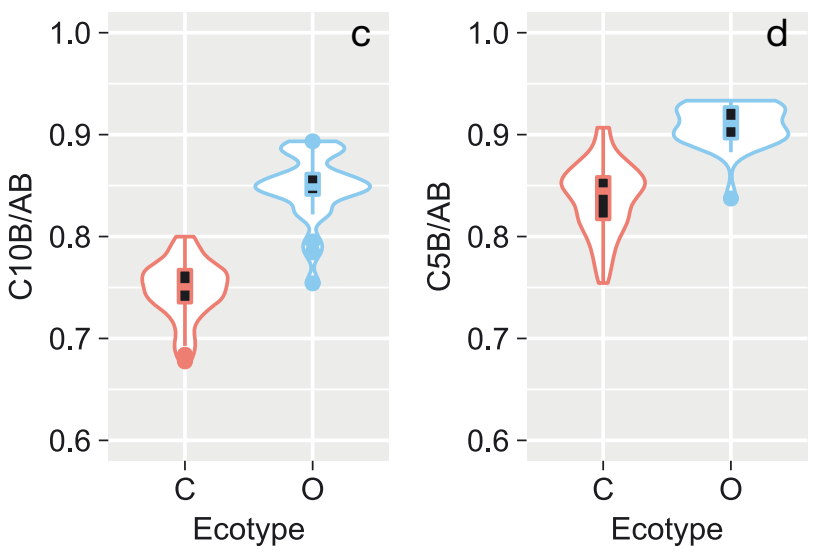

Fig. 3. Violin plots of each index measured on the dorsal fins, (a) C30B/AB, (b) $C 20 B / A B$, (c) $C 10 B / A B, a n d(d) C 5 B / A B$, of coastal $(\mathrm{C})$ and offshore $(\mathrm{O})$ common bottlenose dolphins of southern and southeastern Brazil clustered by $K$-means algorithm. Box: first and third quartiles with the median dividing the box; whiskers: 1.5 times the inter-quartile distance or the extreme values. (See Figs. 1 \& 2 for definitions of C30B/AB etc.) 
Table 1. External characters that may allow field recognition of the offshore and coastal bottlenose dolphin ecotypes in the western South Atlantic Ocean. Within parentheses is the number of images in which each character was opportunistically observed in our dataset

\begin{tabular}{|lccccc|}
\hline Ecotype & Coloration & Dorsal cape & Whitish areas & $\begin{array}{c}\text { Dark spots on } \\
\text { the belly }\end{array}$ & $\begin{array}{c}\text { Stripes from throat to } \\
\text { axillary region }\end{array}$ \\
\hline Offshore & $\begin{array}{c}\text { Darker: being } \\
\text { browner than gray } \\
(\mathrm{n}=10)\end{array}$ & $\begin{array}{c}\text { Distinct } \\
(\mathrm{n}=10)\end{array}$ & $\begin{array}{c}\text { At the tip of dorsal fin } \\
\text { and caudal peduncle } \\
(\mathrm{n}=10)\end{array}$ & $\begin{array}{c}\text { Occasionally } \\
(\mathrm{n}=3)\end{array}$ & $\begin{array}{c}2 \text { narrow stripes } \\
(\mathrm{n}=4)\end{array}$ \\
Coastal & $\begin{array}{c}\text { Pale gray } \\
(\mathrm{n}=10)\end{array}$ & $\begin{array}{c}\text { No sharp demar- } \\
\text { cation }(\mathrm{n}=10)\end{array}$ & $\begin{array}{c}\text { No whitish areas } \\
(\mathrm{n}=10)\end{array}$ & $\begin{array}{c}\text { Never } \\
(\mathrm{n}=5)\end{array}$ & $\begin{array}{c}2 \text { wide bands } \\
(\mathrm{n}=5)\end{array}$ \\
\hline
\end{tabular}

a
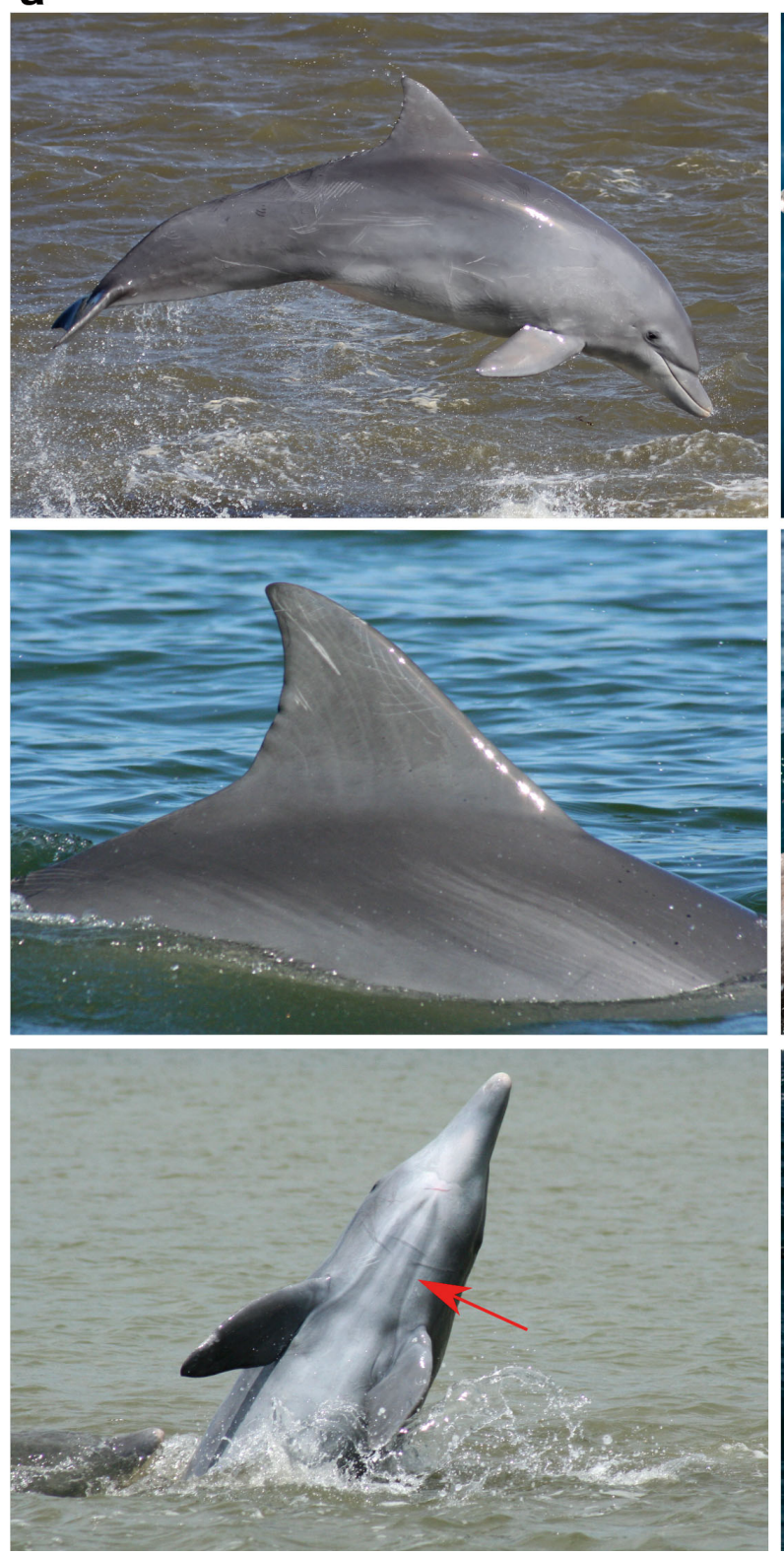

b
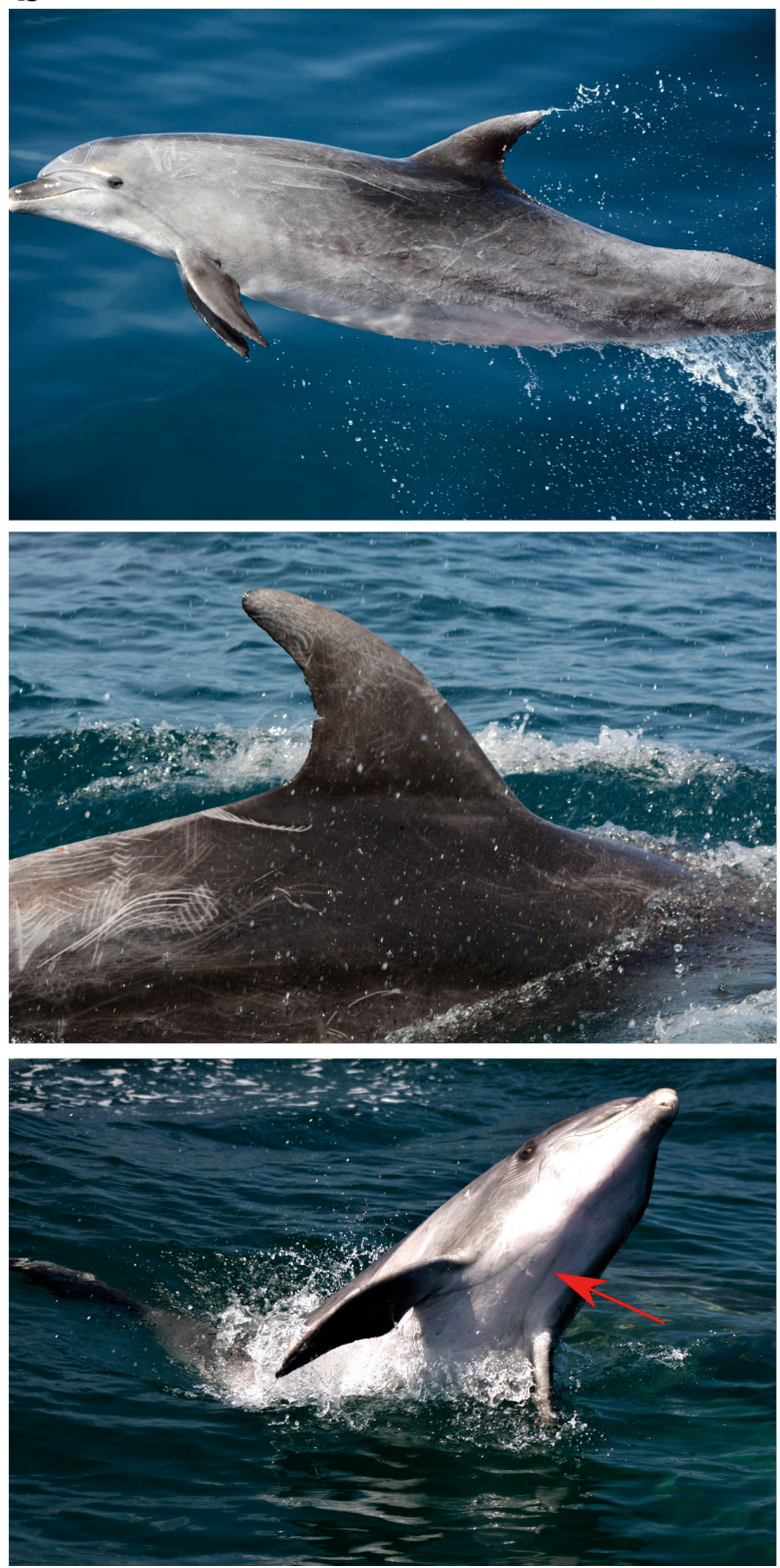

Fig. 4. Color pattern, from top to bottom: dorsum, dorsal fin, and ventral region of the (a) coastal and (b) offshore bottlenose dolphin ecotypes of southern and southeastern Brazil. Arrows indicate narrow stripes and wide bands running from the throat to the axillary area of the offshore and coastal ecotypes, respectively 


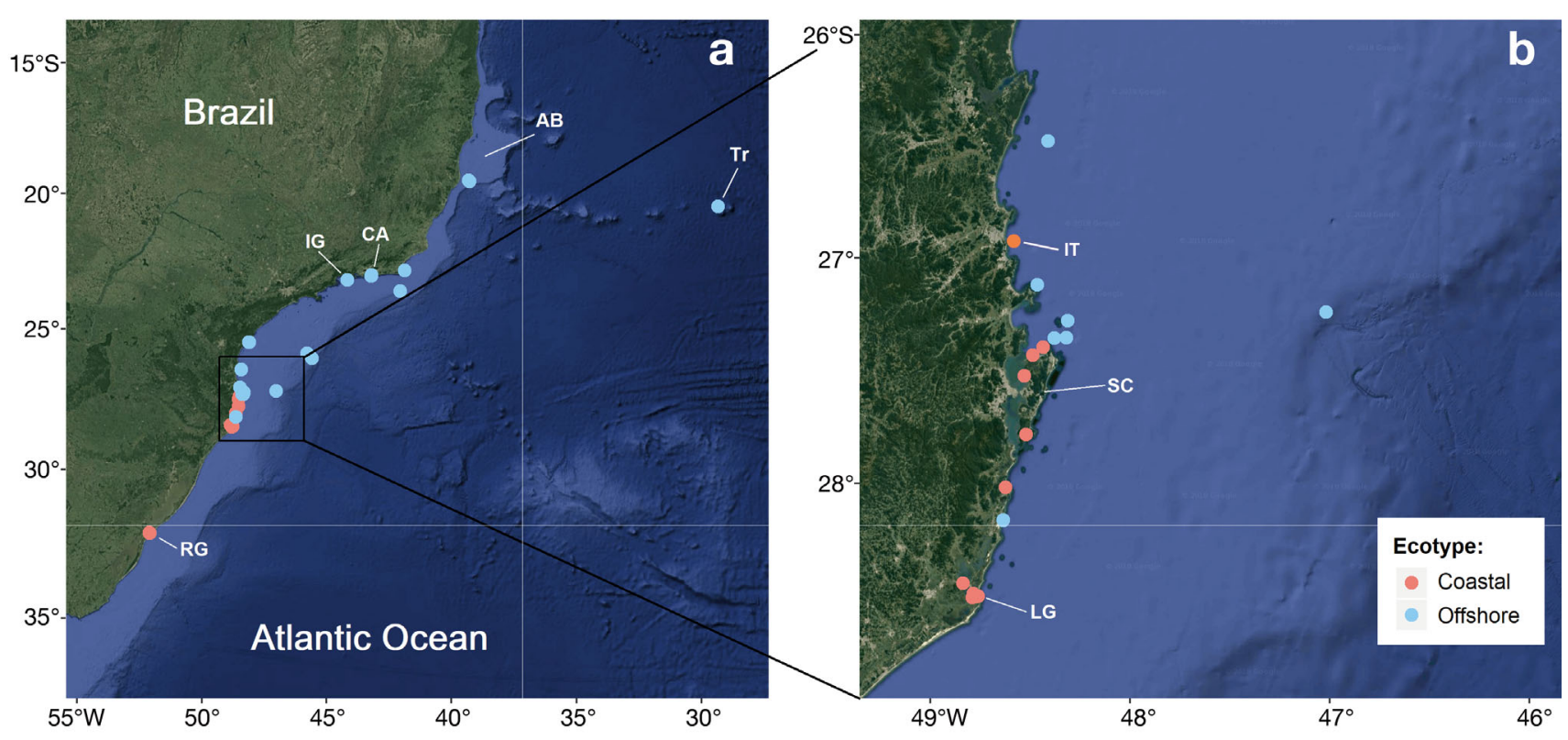

Fig. 5. Distribution of the common bottlenose dolphin ecotypes sighted in (a) the western South Atlantic Ocean (n = 43) and (b) the overlap area in the shallow and nearshore waters. AB: Abrolhos Bank; CA: Cagarras Archipelago; IG: Grande Island; IT: Itajaí River; LG: Laguna; RG: Rio Grande; SC: Santa Catarina Island; Tr: Trindade Island

$(\mathrm{n}=10)$, all offshore individuals $(\mathrm{n}=10)$ were darker with distinct dorsal capes, whitish areas from the dorsal fin to the caudal peduncle (this last feature was not noted for the offshore animal from Trindade Island). Dark spots were noted on the belly of a few offshore dolphins $(\mathrm{n}=3)$, but never in coastal dolphins $(\mathrm{n}=5)$. Two narrow stripes from the throat to the axillary region were observed in all the offshore images examined $(n=4)$, while 2 wide bands were observed in all the coastal dolphins examined $(n=5)$. Differences in the length of the rostrum were also observed between clusters (short rostrum for the offshore and longer for the coastal ecotype; see Fig. S2 in Supplement 1).

\subsection{Distribution, habitat use, and group size of the ecotypes}

The common bottlenose dolphin ecotypes showed distinct distribution patterns (Fig. 5). The coastal dolphins were concentrated in inshore waters and had a limited range that was close to the surf line (surf zone) of southern Brazil. They were frequently found entering riverine and estuarine environments, including coastal bays and lagoons, as far north as the Itajaí River, southern Brazil. The offshore dol- phins were more widely distributed along the Brazilian coast. There was an area of overlap in the distribution of the 2 ecotypes in the shallow and nearshore waters of the southern Brazilian coast (25 $51^{\prime} 50^{\prime \prime} \mathrm{S}$ to $28^{\circ} 29^{\prime} 39^{\prime \prime}$ S).

The habitats used by the ecotypes differed significantly in depth and distance from the coast (Fig. 6a,b). The offshore dolphins had a wider range and used deeper waters (median: $25 \mathrm{~m}$; mean: $110.8 \pm 191.3 \mathrm{~m}$; range: $3-758 \mathrm{~m})$ than the coastal ecotype (median: $3 \mathrm{~m}$; mean: $5.1 \pm 4.4 \mathrm{~m}$; range: $1-$ $18 \mathrm{~m} ; t=-5.89 ; \mathrm{df}=32.2 ; \mathrm{p}<0.05)$; and waters further from shore (median: $8.7 \mathrm{~km}$; mean: $37.6 \pm 62.7 \mathrm{~km}$; range: $0.5-219.5 \mathrm{~km})$ compared to the coastal ecotype (median: $1.6 \mathrm{~km}$; mean: $1.6 \pm 0.9 \mathrm{~km}$; range: $0.1-3.4 \mathrm{~km} ; t=-4.68$; df $=25.8 ; \mathrm{p}<0.05)$.

Group sizes differed considerably between ecotypes (Fig. 6c). The offshore dolphins were observed in larger groups (median: 15 individuals; mean: 26.7 \pm 40.8 individuals; range: $2-200$ individuals) than the coastal dolphins (median: 4 individuals; mean: $4.5 \pm$ 2.0 individuals; range: 1-9 individuals). After omitting a group of 200 offshore dolphins from the dataset (an extreme value that could mask the results), the effect of ecotype was significant $(z=6.1$; $\mathrm{p}<0.05)$, with the model predicting a group size of 19 individuals for the offshore ecotype and 4.5 dolphins for the coastal ecotype. 

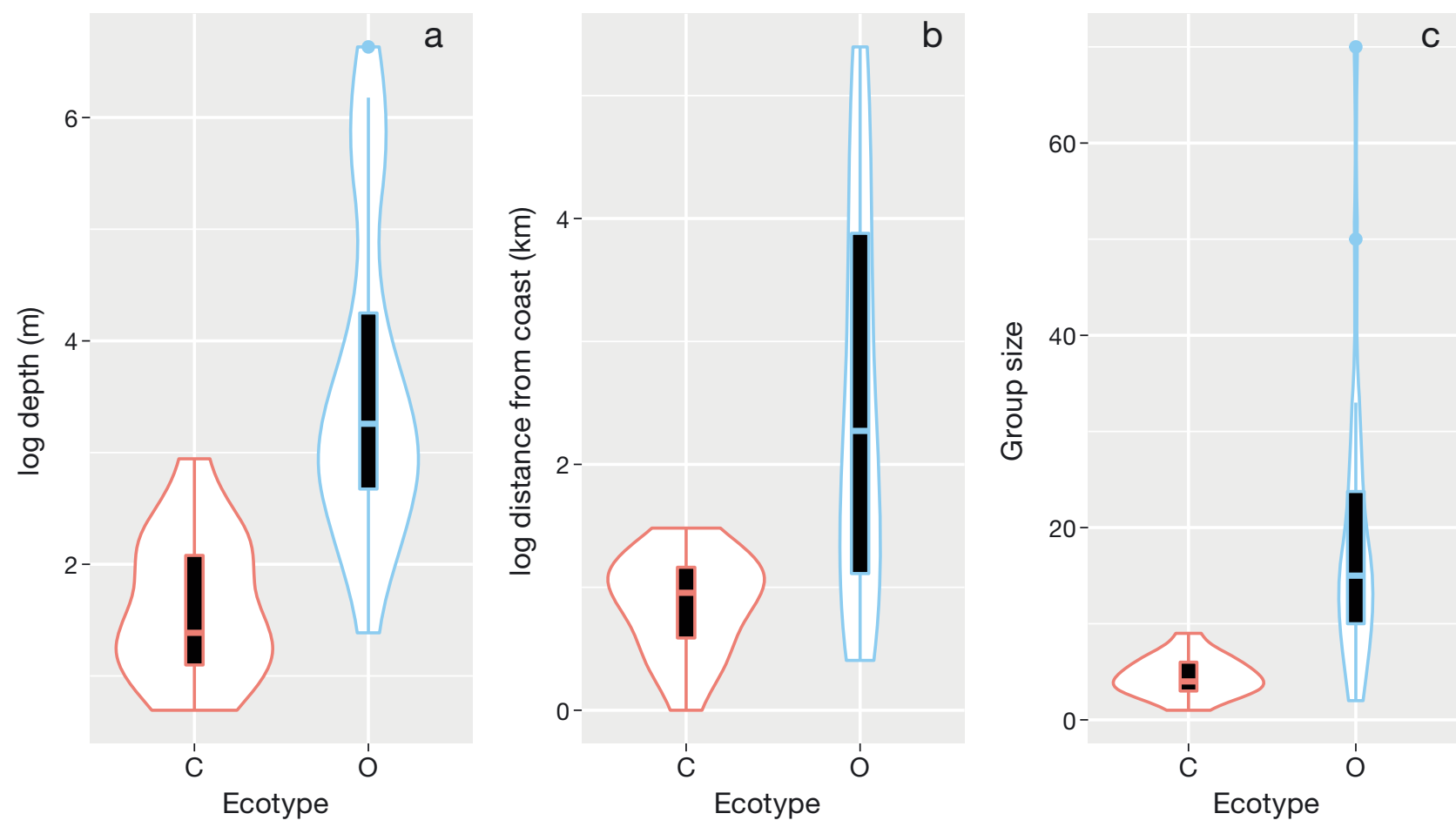

Fig. 6. Violin plots for variation in (a) log of the depth, (b) log of the distance from the coast, and (c) group size between coastal $(\mathrm{C})$ and offshore $(\mathrm{O})$ ecotypes of the common bottlenose dolphin off Brazil. Box: first and third quartiles, with the median dividing the box; whiskers: 1.5 times the inter-quartile distance or the extreme values

\section{DISCUSSION}

\subsection{Field recognition}

Our quantitative analyses confirmed the differentiation of the coastal and offshore ecotypes by dorsal fin shape. As expected, the offshore dolphins showed a more falcate dorsal fin compared to the coastal dolphins, which can easily be observed in the field or by photo-identification. This characteristic was also observed for the offshore dolphin from the western North Atlantic as well as for the dolphin from the Galapagos, and is in agreement with what was recently proposed for the southeast Pacific Ocean (Félix et al. 2018). However, it is important to highlight that we used an extremely small sample size of offshore dolphins from other regions, and further studies with larger sample sizes should be conducted to statistically investigate if falcate dorsal fins can be considered a shared characteristic between common bottlenose dolphins inhabiting deeper waters.

The external morphological characteristics (color pattern and dorsal fin shape) also revealed a clear differentiation between the ecotypes, demonstrating that these characters are useful for field recognition.
These characteristics agree with that previously suggested for the wSAO (Simões-Lopes 1996, Cremer et al. 2009, Lodi 2009) and cited in the literature for the ecotypes in the Southeastern Pacific (Van Waerebeek et al. 1990, Sanino \& Yáñez 2001, Félix et al. 2018). In addition, we observed a distinct dorsal cape, a throat region with a dark W-shaped mark, and 2 narrow stripes from the throat to the axillary region as characters unique to the offshore dolphins. The 2 narrow stripes are also present in offshore animals around the Galapagos Islands, and such a characteristic should also be investigated in closer detail in other offshore populations around the world (see Fig. S4 in Supplement 3).

The whitish patches on the tip of the dorsal fin and tailstock, caused by intraspecific rake marks, were common in the offshore ecotype and present in almost all adult animals, which may aid offshore ecotype recognition at sea (see also Cremer et al. 2009 and our Fig. S5 in Supplement 3). The coastal ecotype also had scratches of social origin, but not the whitish areas characteristic of the offshore dolphins. There might be several reasons for the lack of whitish patches in the coastal ecotype: rake marks may not be concentrated on the tip of the dorsal fin and the 
tailstock, the scars may not be visible due to intrinsic characteristics of the skin (such as healing), or there may be few rake marks. Furthermore, the larger group sizes of the offshore ecotype suggest a higher social activity among offshore dolphins, and perhaps more rake marks. Thus, this characteristic may involve both genetic and behavioral origins.

The only exception to the presence of whitish patches in the offshore dolphins was seen in the dolphins around Trindade Island, the oceanic island furthest from the Brazilian mainland. The dorsal fins of the dolphins from Trindade Island fit precisely within the offshore ecotype group (PCA cluster and Fig. S6 in Supplement 3). Images from other oceanic islands off Brazil, such as the São Pedro and São Paulo Archipelago and Rocas Atoll, were not included in the present study; however, dolphins from these isolated sites have falcate dorsal fins and whitish patches on the peduncle (Ott et al. 2016, C. G. Baracho-Neto pers. comm.), which are characteristics of the offshore ecotype observed in the present study. Variations in the offshore ecotype color pattern, especially in small and isolated populations like that from Trindade Island, may arise for genetic or behavioral reasons. Small resident populations and low genetic variability are characteristics of the offshore bottlenose dolphins occupying the waters around the São Pedro and São Paulo Archipelago (Castilho et al. 2015, Milmann et al. 2017) and Trindade Island (see Carvalho \& Rossi-Santos 2011).

The color patterns found for coastal and offshore ecotypes are similar to those in the western North Atlantic, where the coastal ecotype appears lighter gray, while the offshore ecotype is darker (Turner et al. 2006, Wells \& Scott 2009). The stronger countershading of the offshore ecotype may be an adaptation to the clearer waters of their habitats, where vision may assume greater importance, in contrast to the chronic turbid waters inhabited by the coastal ecotype. In addition to the color patterns, the size of the rostrum may also have adaptive significance.

\subsection{Habitat use and distribution}

Our results showed significant habitat segregation between the 2 wSAO forms, reinforcing that they are different ecotypes. The term 'coastal' ecotype is normally applied to dolphins with a limited range along the surf line (or surf zone) that often occur in inland waters (see Hansen 1990), whereas the term 'offshore' is generally used for groups of dolphins that frequently use open waters not exclusively within continental shelves (e.g. Scott \& Chivers 1990). Here, we observed that the wSAO coastal ecotype inhabits nearshore waters (often close to the surf zone of sandy beaches or rocky shores) and frequently uses inland waters such as bays and coastal lagoons and rivers with deep channels connecting to the open sea of southern Brazil (e.g. Simões-Lopes 1991, Di Tullio et al. 2015). The wSAO offshore dolphins have a wider distribution. In certain places, the distribution includes the coast, although it can also include the entire neritic zone, both on the continental slope and in oceanic waters. The offshore ecotype also occurs regularly near oceanic islands, such as the Trindade Archipelago $(1200 \mathrm{~km}$ from the coast, Carvalho \& Rossi-Santos 2011), São Pedro and São Paulo Archipelago $(1010 \mathrm{~km}$ from the coast, Caon \& Ott 2000, Milmann et al. 2017), and Rocas Atoll (260 km from the coast, Baracho et al. 2007). As our data have shown, groups of 17 to 25 offshore dolphins are common near the coast $(<1 \mathrm{~km})$. Scott \& Chivers (1990) recognized that the offshore common bottlenose dolphin inhabiting the Pacific Ocean also uses waters near the coast and near oceanic islands.

Despite using habitats that are mostly distinct, our results demonstrated that there is some overlap in habitat use between the coastal and offshore ecotypes in both depth (3-18 $\mathrm{m}$ ) and distance from the coast $(1-4 \mathrm{~km})$. This overlap spans the coast from Guaratuba $\left(25^{\circ} 51^{\prime} 50^{\prime \prime} S_{\text {; }}\right.$ the northernmost field record of the coastal ecotype, Simões-Lopes pers. obs.) to Laguna $\left(28^{\circ} 29^{\prime} 39^{\prime \prime} \mathrm{S}\right.$; the southernmost field record of the offshore ecotype, the present study). Nevertheless, there are records of 3 offshore dolphins occupying the same area as coastal dolphins in Bahia San Antonio (40 50' S, 64 $\left.50^{\prime} \mathrm{W}\right)$, Argentina (Vermeulen \& Cammareri 2009, Fruet et al. 2017), an area further south than our study area. Interestingly, the well-known ecotypes of the western North Atlantic also have a small overlap in distribution south of Cape Hatteras despite their generally distinct habitat preferences (Hayes et al. 2017).

These findings reinforce the original idea of a parapatric distribution argued by Toledo (2013) and supported by morphological (Costa et al. 2016) and genetic data (Costa et al. 2015, Fruet et al. 2017). Such differential habitat and possibly prey preferences resulting from ecological differentiation may have also led to the morphological and genetic differences observed between these ecotypes (Costa et al. 2016, Fruet et al. 2017, the present study). These differences seem to be leading to speciation, with the wSAO ecotypes being described as different subspecies (Costa et al. 2016) - Tursiops truncatus gephyreus (coastal) 
and T. truncatus truncatus (offshore). Considering the morphospace concept, such variations are typical of geographic ranges with overlapping boundaries that serve as zones of hybridization or ecological escarpment. Thus, the concept of parapatric distribution (see Bull 1991) is valid here. The existence of parapatry reinforces the arguments for a preliminary differentiation between the ecotypes involving some reproductive isolation and is usually associated with taxonomic separation of closely related and morphologically similar taxa on a fine geographic scale (Bull 1991).

In the current study, the feasibility of identifying bottlenose dolphin ecotypes based on external morphological characteristics was confirmed, facilitating recognition in the field. This agrees with what has been previously described through cranial morphology (Costa et al. 2016) and genetic analyses (Fruet et al. 2017), and can be considered as useful complementary information for the taxonomic debate, increasing the support for the presence of distinct subspecies in the wSAO, as well as contributing to a better understanding of their ecology.

Acknowledgements. The PMC-BS is one of the monitoring programs required by Brazil's federal environmental agency, IBAMA, for the environmental licensing process of the oil production and transport by Petrobras at the Santos Basin pre-salt province (process no. 02001.114279/2017-80, ACCTMB no. 657/2015). We also thank Wayne McFee (NOAA/NCCOS/ NOS) for kindly providing the offshore photography from the western North Atlantic; Cibele Sanches for the photography around the Galapagos Islands; and Dr. Patricia E. Rosel for the identification of the wNA ecotype by the genetic data. We are grateful to Lynsey Wilcox for her helpful comments and English review. We thank Instituto Baleia Jubarte for the support to the Expedition to Trindade and Martin Vaz Islands. The results of this study between 2011/2012 and 2014/2015 are part of the Projeto Ilhas do Rio (Ilhas do Rio Project), performed by the Instituto Mar Adentro (Mar Adentro Institute) and sponsored by Petrobras (Brazilian Petroleum Corporation) (grant numbers 6000.0064815.11.2 and 6000.0086840 .13 .2 , respectively). Projeto Baleias \& Golfinhos do Rio de Janeiro has the support of the Programa Marinho/ WWF-Brasil (grant number CPT 00776-2016) and Programa Costa Atlântica/Fundação SOS Mata Atlântica (2016-2017) (donation without number).

\section{LITERATURE CITED}

Acevedo-Gutiérrez A (2009) Habitat use. In: Perrin WF, Würsig B, Thewissem JGM (eds) Encyclopedia of marine mammals, $2^{\text {nd }}$ edn. Academic Press, Galveston, TX, p 524-529

Baracho CG, Cipolotti S, Marcovaldi E, Apolinário M, Silva MB (2007) The occurrence of bottlenose dolphins (Tursiops truncatus) in the biological reserve of Atol das Rocas in north-eastern Brazil. Mar Biodivers Rec 1:e75

Bull CM (1991) Ecology of parapatric distributions. Annu
Rev Ecol Evol Syst 22:19-36

Caon G, Ott PH (2000) Ocorrência e fotoidentificação do golfinho-nariz-de-garrafa (Tursiops truncatus) em águas oceânicas brasileiras no Arquipélago de São Pedro e São Paulo. In: Castello HP, Junin M (eds) $9^{a}$ Reunion de trabajo de especialistas en mamíferos acuaticos de América del Sur. Museo Argentino de Ciencias Naturales Bernadino Rivadavia, Buenos Aires, p 20

Carvalho MS, Rossi-Santos MR (2011) Sightings of the bottlenose dolphins (Tursiops truncatus) in the Trindade Island, Brazil, South Atlantic Ocean. Mar Biodivers Rec 4:e15

Castilho CS, Pedone-Valdez F, Bertuol F, Fruet P and others (2015) Insights about the genetic diversity and population structure of an offshore group of common bottlenose dolphins (Tursiops truncatus) in the Mid-Atlantic. Genet Mol Res 14:3387-3399

Costa APB, Fruet P, Daura-Jorge FG, Simões-Lopes PC, Ott PH, Valiati VH, Oliveira LR (2015) Bottlenose dolphin communities from the southern Brazilian coast: Do they exchange genes or are they just neighbours? Mar Freshw Res 66:1201-1210

Costa APB, Rosel PE, Daura Jorge FG, Simões Lopes PC (2016) Offshore and coastal common bottlenose dolphins of the western South Atlantic face to face: what the skull and the spine can tell us. Mar Mamm Sci 32:1433-1457

* Cremer MJ, Barreto AS, Hardt FAS, Tonello AJ Jr, Mounayer R (2009) Cetacean occurrence near an offshore oil platform in southern Brazil. Biotemas 22(3):247-251

Di Tullio JC, Fruet PF, Secchi ER (2015) Identifying critical areas to reduce bycatch of coastal common bottlenose dolphins Tursiops truncatus in artisanal fisheries of the subtropical western South Atlantic. Endang Species Res 29:35-50

Eble GJ (2000) Theoretical morphology: state of the art. Paleobiology 26:520-528

F Félix F, Van Waerebeek K, Sanino GP, Castro C, Van Bressem MF, Santillán L (2018) Variation in dorsal fin morphology in common bottlenose dolphin populations Tursiops truncatus (Cetacea: Delphinidae) populations from the Southeast Pacific Ocean. Pac Sci 72:307-320

F Fruet PF, Secchi ER, Di Tullio JC, Simões-Lopes PC and others (2017) Genetic divergence between two phenotypically distinct bottlenose dolphin ecotypes suggests separate evolutionary trajectories. Ecol Evol 7:9131-9143

Hansen LJ (1990) California coastal bottlenose dolphins. In: Leatherwood S, Reeves RR (eds) The bottlenose dolphin. Academic Press, San Diego, CA, p 403-420

Hayes SA, Josephson E, Maze-Foley K, Rosel PE (2017) US Atlantic and Gulf of Mexico marine mammal stock assessments 2016. NOAA Tech Memo NMFS-NE 241

Hersh SL, Duffield DA (1990) Distinction between northwest Atlantic offshore and coastal bottlenose dolphins based on hemoglobin profile and morphometry. In: Leatherwood S, Reeves RR (eds) The bottlenose dolphin. Academic Press, San Diego, CA, p 129-139

Hershkovitz P (1966) Catalog of living whales. Bull US Natl Mus 246:1-259

Lodi L (2009) Fidelidade de área, características de grupo e organização social de Tursiops truncatus (Cetacea, Delphinidade) no Arquipélago das Cagarras, Rio de Janeiro, RJ, Brasil. PhD dissertation, Universidade Federal Fluminense, Niterói, RJ

Louis M, Viricel A, Lucas T, Peltier H and others (2014) Habitat-driven population structure of bottlenose dol- 
phins, Tursiops truncatus, in the North-East Atlantic. Mol Ecol 23:857-874

Menotti-Raymond M, O'Brien S (1993) Dating the genetic bottleneck of the African cheetah. Proc Natl Acad Sci USA 90:3172-3176

Milmann LC, Danilewicz D, Baumgarten J, Ott PH (2017) Temporal-spatial distribution of an island-based offshore population of common bottlenose dolphins (Tursiops truncatus) in the equatorial Atlantic. Mar Mamm Sci 33: 496-519

Milot E, Weimerskirch H, Duchesne P, Bernatchez L (2007) Surviving with low genetic diversity: the case of albatrosses. Proc R Soc B 274:779-787

Morteo E, Rocha-Olivares A, Morteo R, Weller DW (2017) Phenotypic variation in dorsal fin morphology of coastal bottlenose dolphins (Tursiops truncatus) off Mexico. PeerJ 5:e3415

Oksanen, J, Blanchet FG, Friendly M, Kindt R and others (2018) vegan: community ecology package, version 2.4-6. https://cran.r-project.org/package=vegan

Ott PH, Barreto AS, Siciliano S, Laporta P and others (2016) Report of the Working Group on Taxonomy and Stock Identity of bottlenose dolphins in the Southwest Atlantic Ocean. Lat Am J Aquat Mamm 11:16-28

Pante E, Simon-Bouhet B (2013) marmap: a package for importing, plotting and analyzing bathymetric and topographic data in R. PLOS ONE 8:e73051

Perrin WF (2009) Geographic variation. In: Perrin WF, Wursig B, Thewissen JGM (eds) Encyclopedia of marine mammals, $2^{\text {nd }}$ edn. Academic Press, San Diego, CA, p 492-498

*Perrin WF, Thieleking JL, Walker WA, Archer FI, Robertson KM (2011) Common bottlenose dolphins (Tursiops truncatus) in California waters: cranial differentiation of coastal and offshore ecotypes. Mar Mamm Sci 27:769-792

R Core Team (2014) R: a language and environment for statistical computing. R Foundation for Statistical Computing, Vienna. www.r-project.org

Rosel PE, Hansen L, Hohn AA (2009) Restricted dispersal in a continuously distributed marine species: common bottlenose dolphins Tursiops truncatus in coastal waters of the western North Atlantic. Mol Ecol 18:5030-5045

Sanino GP, Yáñez J (2001) Nueva técnica de video identificación y estimación de tamaño poblacional en cetáceos, aplicada en delfines nariz de botella, Tursiops truncatus, de Isla Choros, IV región de Chile. Bol Mus Nac Hist Nat Chile 50:37-63

Schneider CA, Rasband WS, Eliceiri KW (2012) NIH Image to ImageJ: 25 years of image analysis. Nat Methods 9: $671-675$

Scott MD, Chivers SJ (1990) Distribution and herd structure

Editorial responsibility: Brent Stewart,

San Diego, California, USA of bottlenose dolphins in the eastern tropical Pacific Ocean. In: Leatherwood S, Reeves RR (eds) The bottlenose dolphin. Academic Press, San Diego, CA, p 387-402

Simões-Lopes PC (1991) Interaction of coastal populations of Tursiops truncatus (Cetacea, Delphinidae) with the mullet artisanal fisheries in southern Brazil. Biotemas 4(2): 83-94

Simões-Lopes PC (1996) Offshore and coastal bottlenose dolphins on southern Brazil: preliminary comparisons on coloration. In: Aguayo A, Yánez J, Vallejos V (eds) $7^{a}$ Reunion de trabajo de especialistas en mamíferos acuaticos de América del Sur, Chile. Universidad Austral do Chile, Valdivia, p 84

Tezanos-Pinto G, Baker CS, Russell K, Martien K and others (2009) A worldwide perspective on the population structure and genetic diversity of bottlenose dolphins (Tursiops truncatus) in New Zealand. J Hered 100:11-24

Toledo GAC (2013) Variação geográfica em crânios de golfinhos-nariz-de-garrafa, Tursiops Gervais, 1855, no Atlântico Ocidental. PhD dissertation, Universidade Federal da Paraíba, João Pessoa, PB

Turner JP, Clark LS, Haubold EM, Worthy GAJ, Cowan DF (2006) Organ weights and growth profiles in bottlenose dolphins, Tursiops truncatus, from the northwestern Gulf of Mexico. Aquat Mamm 32:46-57

Van Waerebeek K, Reyes JC, Read AJ, McKinnon JS (1990) Preliminary observations of bottlenose dolphins from the Pacific coast of South America. In: Leatherwood S, Reeves RR (eds) The bottlenose dolphin. Academic Press, San Diego, CA, p 143-154

Venables WN, Ripley BD (2002) Modern applied statistics with S, $4^{\text {th }}$ edn. Springer, New York, NY

Vermeulen E, Cammareri A (2009) Variation in external morphology of resident bottlenose dolphins in Bahía San Antonio, Patagonia, Argentina. J Mar Anim Ecol 2:3-6

Weller DW (1998) Global and regional variation in the biology and behavior of bottlenose dolphins. PhD dissertation, Texas A\&M University, College Station, TX

Wells RS, Scott MD (2009) Common bottlenose dolphin. In: Perrin WF, Wursig B, Thewissen JGM (eds) Encyclopedia of marine mammals, $2^{\text {nd }}$ edn. Academic Press, San Diego, CA, p 249-255

West-Eberhard MJ (2003) Developmental plasticity and evolution. Oxford University Press, New York, NY

*Wickert JC, von Eye SM, Oliveira LR, Moreno IB (2016) Revalidation of Tursiops gephyreus Lahille, 1908 (Cetartiodactyla: Delphinidae) from the southwestern Atlantic Ocean. J Mammal 97:1728-1737

Yee TW, Stoklosa J, Huggins RM (2015) The VGAM package for capture-recapture data using the conditional likelihood. J Stat Softw 65:1-33

Submitted: May 2, 2018; Accepted: May 21, 2019

Proofs received from author(s): September 6, 2019 